\title{
IAMJ
}

INTERNATIONAL

AYURVEDIC

MEDICAL JOURNAL

ISSN: 2320-5091

Impact Factor: 6.719

\section{AN INSIDE REVIEW OF DANTA SHAREER w.S.r. to KRIMIDANTA (DENTAL CARIES)}

\author{
Ankush Bhardwaj ${ }^{1}$, H S Bali ${ }^{2}$ \\ ${ }^{1}$ Associate Professor, Department of Shalakya Tantra, Jammu Institute of Ayurveda and Research, Nardani, \\ Jammu, J\&K, India \\ ${ }^{2}$ Associate Professor, Department of Rachna Shareer, Jammu Institute of Ayurveda and Research, Nardani, \\ Jammu, J\&K, India
}

Corresponding Author: ankush.bhardwaj84@gmail.com

https://doi.org/10.46607/iamj3008122020

(Published online: December 2020)

Open Access

(C) International Ayurvedic Medical Journal, India 2020

Article Received: 09/12/2020 - Peer Reviewed: 09/12/2020 - Accepted for Publication: 10/12/2020

D) Check for updates

\section{ABSTRACT}

Teeth constituents the most important organ for mechanical digestion in the body. Unless the food is pulverized by the teeth it cannot be chemically digested by the enzymes, hence diseased teeth and gums often lead to indigestion and inadequate utilization of the ingested food leading to malnutrition. Teeth is also a hardest and most stable tissue in the body along with the functions of oral cavity possesses high cosmetic importance. DantaShareera i.e. regarding the anatomy of the teeth there is less explored in the study of Ayurveda, the matters is scattered here and there, and it needs a good compilation to meet the today's science.

Dental caries (Krimidanta) is one of the most common of all diseases and still a major cause for loss of teeth. There is practically no geographic area in the world whose inhibition does not exhibit some evidence of dental caries. It affects persons of both genders in all races, all socio-economical strata and every age group. The first nationwide survey by the dental council has shown that dental caries is prevalent among $63 \%$ of 15 years old and around $80.2 \%$ among adults.

Keywords: DantaShareera, Dental caries (Krimidanta), Oral cavity 


\section{INTRODUCTION}

The Vedic literatures are considered as the oldest and most authentic treasure of knowledge to the mankind yet available. In Rigveda there is a description - Usha dressed herself in such a way, how a wife is attracted by her husband and showed her Danta Raji through smile. ${ }^{1}$ Also in this Veda word danta is used, but there are something compared with teeth. ${ }^{2}$ Ashwini Kumar physician of God have repaired teeth of Pooshana. ${ }^{3}$ Dental caries (krimidanta) is one of the most common of all diseases and still a major cause for loss of teeth. There is practically no geographic area in the world whose inhibition does not exhibit some evidence of dental caries. It affects persons of both genders in all races, all socio-economical strata and every age group. The first nationwide survey by the dental council has shown that dental caries is prevalent among $63 \%$ of 15 years old and around $80.2 \%$ among adults. Keeping in view, the understanding of Dantashareera as per Ayurvedic texts, the specific target to check the structural changes in krimidanta, the present study is undertaken to put an effort for updating concepts on Danta Shareera and Krimidanta.

\section{Materials and Methods}

The Vedic literatures are considered as the oldest and most authentic treasure of knowledge. It is quoted in Atharvaveda, may the power of speech intact in my mouth, the vital birth in my nostril, the sight of the eyes, the hearing in my ears, that may hair never grow white and teeth, redden, let there be great strength in my arms. ${ }^{4}$ By Garbopanishad, it is mentioned that, Dantamoola occurs in VII ${ }^{\text {th }}$ month of intrauterine life. ${ }^{5}$ According to Sukhabodha, during intrauterine life guda (anus) and danta (teeth) will develop in $\mathrm{VI}^{\text {th }}$ month. ${ }^{6}$ In Ayurveda, Danta is defined as Charvanasadanaasthani dashan ${ }^{7}$ - A type of bone helps in mastication, Sukhannasyacharvanasadaneasthibhede ${ }^{8}$ - A masticatory apparatus is type of bone which helps in mastication of food. In the sixth month of intrauterine life both the guda (anus) and danta (teeth) will develop. ${ }^{9}$ According to Charaka all the indriya, anga and pratyanga, develops in the third month of intrauterine life, except these other factors like teeth, mustache, beard, auxiliary hairs, pubic hairs etc. will de- velops after birth. ${ }^{10}$ Chakrapani commenting on, nitya and anityaof this sloka, he explains danta(teeth ) as anitya, because they fall before death of a person ${ }^{11}$. Both the Charaka and Sushruta consider teeth as hard structure and enumerated in the list of body parts derived from father. ${ }^{12,13}$ Dashanasturuchaka - while explaining types of bone, the teeth is considered under type of asti called ruchaka ${ }^{14}$ Sharangadhara considered dantaas upadatu of asti. ${ }^{15}$ By Bhavaprakash, mukh, talu, two hanu, danta and danta vesta are considered as upangof shira. ${ }^{16}$ Teeth is gaurava i.e. partake of mahabhuta of prithvi. ${ }^{17}$ According to Kashyapa, here in deed 32 teeth are in human beings, therein 8 erupt once called sakrujata and become the teeth mounted in own/original(roots), so rest are dvija (erupting twice).$^{18}$ While explaining number of bones Charaka explains that, including teeth, teeth sockets and nails there are 360 bones in body, among them teeth are 32 and sockets (dantaulukala) also 32 in number. ${ }^{19}$ In Bhela samhita ${ }^{20}$ and Ashtanga Sangraha $^{21}$ also we get same description. Sushruta etc. they count only 300 bones, among them the bone lies above the neck are 63 and the teeth are 32 among these 63 types bones. ${ }^{22}$ Bhavaprakasha also given the same explaination. ${ }^{23}$ There in middle upper row are two named Rajadanta (central incisors), on the both sides are Vasta (lateral incisors), lateral to these two are Damstra (canine), rest grow in original roots and are called Hanavya, similarly these are on lower jaw. Though the name given here is neither given by Charaka etc. authors, only Kashyapa ${ }^{24}$ explains about the nomenclature of teeth.

Krimidanta is vataja, tooth destructing disease, affecting due to oral unhygienic condition like improper brushing of tooth, improper washing of mouth, biting the hard items, and picking of teeth with needles neglecting the danta moola rogas like dantasharkara, kapalika, shyavadanta etc. Krimidanta one of dantagataroga by all acharyas but classification of all achary is not same. According to Sushruta, Bhavamisra and Madavakar - they are 8 types, According to Vagbhata and Sharangadhara - 10 types, Where there will be visheshvedana due to krimikrutachidra in the 
danta is called as krimidanta. ${ }^{25}$ According to Ashtang Hridaya, by over indulgence in foods as fish, meat of buffalo and boar (tusked wild pig), uncooked mulaka (radish), curds, milk, sour gruel, sugar cane juice and molasses; sleeping with face down, aversion to cleaning of teeth, improper conduct of therapies such as smoke inhalation, emesis, holding liquids in mouth, shiraveda etc. The doshaskapha being predominant among them, get aggravated and produce diseases in the interior of mouth ${ }^{26}$. According to Madavnidhana, excessive eating of , curd, milk and fish will causes aggravation of all doshas with kaphas predominance and causes for mukha roga. ${ }^{27}$ Nidana (etiological factors) of krimidanta is not specially mentioned anywhere in samhitas, but we can get nidana for all mukharogas. All the dhosas among which vata predominant invading the tooth along with its root dries up the marrow inside and causes the waste product of food to fill up the cavity. Due to putrefaction setting in, minute (invisible) worms develop there, leading to appearance of severe pain and its mitigation both without any reason, profound discomfort, black color, shakiness, swelling, discharge of pus and blood. This disease is spoken as krimidanta. ${ }^{28}$

Due to Nidana------- vatapradhantridoshaprakopa-----invading the tooth---- dries up the marrow along its root------ formation of cavity------causes the waste product of food to fill up the cavity------putrefaction------ Development of worms (Krimi)

In symptoms of krimidanta initially danta becomes krishnavarni, then there will be cavity formation, becomes chala (loose), discharging, swollen and severely painful, pain appearing without any apparent cause. It is caused by vata. ${ }^{29,30,31}$ According to Hareet, the raktajadantaroga causes itching, bleeding, swelling in gums and become red that causes hole in root of teeth, it leads to sever pain and cracks occurs in gums that disease is krimija dantaroga. ${ }^{32}$ Severe pain and its mitigation both without any reason, profound discomforteness, black color, shakiness, swelling, discharge of pus and blood. These are the symptoms explained by Vagbhat - I and II. ${ }^{33}$ The teeth which are erupted in sixth month are inverted, dirty, discolored and affected by krimi. ${ }^{34}$

Dental caries is progressive bacterial damage to teeth exposed to the saliva. Caries is one of the most common of all diseases and still a major cause of loss of teeth. The ultimate effect of caries is to break down enamel and dentine and thus open a path for bacteria to reach the pulp. The consequence are inflammation of the pulp and later, of the periapical tissue. Acute pulpitis and apical periodontitis caused in this way are the most common causes of toothache. Infection can spread from the periapical region to the jaw and beyond.The word caries means microbial destruction or necrosis of teeth ${ }^{35}$ Dental caries has been defined as "a localized post eruptive pathological process of external origin involving softening of the hard tooth tissue and proceeding to the formation of a cavity". ${ }^{36}$

Dental caries, which had been described over a hundred years ago, is simple in concept. Bacteria such as the mutans streptococci and lactobacilli are constituents of dental plaque. These bacteria produce acids on metabolizing fermentable carbohydrates. Acids such as lactic acid, propionic acid, formic acid and acetic acid can dissolve the tooth substance. When tooth material dissolves, there is leaching out of calcium and phosphate. This process is called 'demineralization'.

Bacteria like Mutansetc $\longrightarrow$ produce oraganic acids tion) cavitation if progress, leads to loss of tooth structure.

This occurs below the surface zone of enamel causing subsurface demineralization. Clinically, this appears as a white spot lesion because the loss of tooth mineral changes the refractive index compared with that of normal enamel. When subsurface demineralization progresses to such an extent that, the surface layer loses all its support and cavitation occur. During the course of this process, 'remineralization' occurs. This involves replacement of tooth minerals. 
Table 1: We can compare the Krimidanta with Dental Caries

\begin{tabular}{|l|l|l|}
\hline S.No & Symptoms of krimidanta & Symptoms of caries \\
\hline 1 & Krishna danta & Blackish discolorisation \\
\hline 2 & Chidra & Cavitation \\
\hline 3 & vedana & Pain \\
\hline 4 & Chala & Movable teeth \\
\hline 5 & Samsarambha & Swelling in Gums \\
\hline
\end{tabular}

\section{DISCUSSION}

When we go through the definition of Krimidanta we can say that Krimi, Chidra (cavity) and Vedana are the cardinal signs and symptoms of Krimidanta $\mathrm{Ni}$ danapanchaka are the tools used to examine and diagnose the disease. The nidana can be classified as Aharaja and Viharajanidanas.Among the samanyanidanasksheera, masha, iksurasa are the kaphakaranidanas. Dadhi is kapha and pittakra, sukta is raktapittakara. Phanita and apakwamoolaka are tridoshkara, also among these nidanas most are explained as nidanas for krimi also, like mamsa, matsya, dadhi, ksheera, suktha etc.

Among the viharajanidanas most are vishamadantadhavana, vishamadhoomapana, vishamagandusha, vishamavamana and siraveda can be considered as nidanas for krimidanta as these are mainly vatakara and krimidanta is vatapradhanavyadhi. As krimidanta is vatadoshapradhanavyadhi, poorvaroopalakshanas are avyakta. Hence mild or very less symptoms prior to the roopa or actual manifestation of krimidanta may be taken as poorvaroopa. When the avyakta lakshanas becomes completely vyakta and manifest the disease krimidanta they are called as roopa.

Initially there will be krishnavarnata of danta as the prakupitavata takes ashraya in danta. Then there will be formation of cavity as the vata does dantagatamajjashosha leading to sushirata of danta. Due to majjakshaya again there will be vataprakopa, so severe dantashula is experienced. The annamala gets collected in that cavity and petrification starts there so the shotha and srava are seen. Then krimi develops there which may starts eating danta, dantagatamajja and dantamamsa. So, dantabandhana becomes loose and it becomes chala. As krimidanta is vatapradha- navyadhi severe pain and pain without any reason may be present.

Nidanasevana leads to vatapradhanatridoshaprakopa. Viharajanidanas are mainly contributes for vataprakopa where as Aharajanidanas leads to kaphapradhanatridoshaprakopa. These vitiated doshas are waiting for favorable condition to produce disease. When the person indulges into nidana pertaining to danta like vishamadantadhawana and vishamagandusha, the vitiated vatadosha takes ashraya in danta. Due to Ashrayashrayi bhava of vata and Asthi, as danta is one type of Asthi named as Ruchakasti. Then due to rukshaguna of vata there will be Dantagatamajjashosha. Along with this if the nidanas are continued the annamala gets lodged in the cavity. If this lodged food is not removed by proper brushing, then putrefaction starts. This provides favorable condition for krimiutpatti in danta and the disease krimidanta manifests.

\section{CONCLUSION}

Dantas are also having its importance in clinical side. Krimidanta can be correlated with Dental caries which is major cause for partial or complete loss of tooth structure. On radiological examination structural changes like, radiolucency of enamel, dentin and pulp, discontinuation of lamina dura and widening of periodontal ligamental space are seen in almost all patients suffering from krimidanta.

\section{REFERENCES}

1. Rigveda-samhita, Pandit Ramgovinda Trivedi, Reprint 2003, vol II, Chaukhambha Surabharati Prakashana, PP 25(18/124/7)

2. K.L.Joshi. Rigveda Samhita, Sanskrita text, $I^{\text {st Ed }}$ 2000, Jaykrishnadas Sansrita Series, Chaukhamba orientalia Varanasi, PP 1060,472(6/75/11) 
3. Dr. Vichanda M. A. Atharvaveda, reprint 1997, Munshiram Manoharlal publication pvt 1td, PP 939 $(5 / 20 / 4)$

4. Dr. Vichanda M.A. Atharvaveda, reprint 1997, Munshiram Manoharlal publication pvt ltd, PP 939 $(5 / 23 / 31)$

5. Sri. Taranath Vachaspati Bhattaacharya, Vachaspatyam, $3^{\text {rd }}$ Ed, vol 5, Chaukhambha Sanskrit Series, Varanasi. 1969, PP 3463.

6. Raja-Radhakantadev, Shabdakalpadruvam, reprint 1988, vol 2, Nag publishers, Delhi-7, PP 681.

7. Kaviraj Umeshchandra Gupta, VaidyakaSabdasindhuh, $5^{\text {th }}$ Ed, Chaukhambha Orientalia, Varanasi, 2005, PP 530.1212.

8. Sri. Taranath Vachaspati Bhattaacharya, Vachaspatyam, $3^{\text {rd }}$ Ed, vol 5, Chaukhambha Sanskrit Series, Varanasi. 1969, PP 3463.

9. Raja-Radhakantadev, Shabdakalpadruvam, reprint 1988, vol 2, Nag publishers, Delhi-7, PP 681. (Sukhabodha)

10. Agnivesha: Charaka Samhita, Savimarsha-vidyotini hindi vyakyapeth, Ed 2005 Chaukhambha Bharati Academy, Varanasi, PP 872, 1023. (Ca. Sha 4/14)

11. Agnivesha: Charaka Samhita, $5^{\text {th }} \mathrm{Ed}$ Commentary of Chakrapanidatta Chaukhambha Sanskrita Bhavana, Varanasi, PP 318. (Ca. Sha 4/14)

12. Agnivesha: Charaka Samhita, Ed 2005, Savimarshavidyotini hindi vyakyapeth, Chaukhambha Bharati Academy, Varanasi, PP 856, 1023. (Ca.Sha 3/7)

13. Susruta: Susruta Samhita, Edited by P.V. Sharma, Ed 2004, Vol 1, Chaukhambha Visvabharati, Varanasi, PP 148. (Su. Sha 3/33)

14. Vagabhata: Astanga Samgraha, Prof. K.R. Srikantamoorthy, $5^{\text {th }}$ Ed, Chaukhambha Orientalia, Varanasi, 2005.PP 69 (A.Sa. Sha 5/43)

15. Sharangadhara: Sharangadhara Samhita, Prof. K.R. Srikantamoorthy; $3^{\text {rd }}$ Ed 1997, Chaukhambha Orientalia, Varanasi. PP 22:335 (Sha. poo 5/16-17)

16. Bhavamishra: Bhavaprakasha, Bramhashankar Misra \& Sri. Rupalaji Vaisya; $11^{\text {th }}$ Ed 2004. ChaukhambhaSanskrita Bhavana Varanasi, PP 31(Bha poo 3/69)

17. Bhela: Bhela Samhita, Dr. K.H. Krishnamurthy. Ed 2003, Chaukhambha Bharati Academy. Varanasi, PP 225 (Bh.Sa. Sha 5/17)

18. Kashyapa: Kasyapa Samhita or Vruddajivakiya tantra, Text with English translation \& Commentary, P.V. Tewari. $1^{\text {st }}$ Ed, Chaukhambha Visvabharati, Varanasi. PP 16 (Ka Su 20/4)
19. Agnivesha: Charaka Samhita, Savimarsha-vidyotini hindi vyakyapeth, Ed 2005 Chaukhambha Bharati Academy, Varanasi, PP 912, 1023.(Ca. Sha 7/6)

20. Bhela: Bhela Samhita, Dr. K.H. Krishnamurthy. Ed 2003, Chaukhambha Bharati Academy. Varanasi, PP 235 (Bh.Sa. Sha 7/12)

21. Vagabhata: Astanga Samgraha, Prof. K.R. Srikantamoorthy, $5^{\text {th }} \mathrm{Ed}$, Vol 2, Chaukhambha Orientalia, Varanasi, 2005.PP 68 (A.Sa.Sha 5/42)

22. Susruta: Susruta Samhita, Edited by P.V. Sharma, Ed 2004, Vol 1, Chaukhambha Visvabharati, Varanasi, PP 174. (Su.Sha 5/19)

23. Bhavamishra: Bhavaprakasha, Bramhashankar Misra \& Sri. Rupalaji Vaisya; $11^{\text {th }}$ Ed 2004. ChaukhambhaSanskrita Bhavana Varanasi, PP 46 (Bha poo 3/154156)

24. Kashyapa: Kasyapa Samhita or Vruddajivakiya tantra, Text with English translation \& Commentary, P.V. Tewari, $1^{\text {st }}$ Ed, Chaukhambha Visvabharati, Varanasi. PP 16 (Ka Su 20/4)

25. Shastri P.V. Sharangdhara Samhita, $5^{\text {th }}$ ed, Choukhambha Orientalia; Varanasi; 2002: pp 109

26. Vagabhata: Astanga Samgraha, Prof. K.R. Srikantamoorthy, $4^{\text {th }} \mathrm{Ed}$, Vol 3, Chaukhambha Orientalia, Varanasi, 2005.PP 213 (A.S. U 25/3)

27. Madhavakara: Madhava Nidana, Sri Yadunandan Upadhyaya, Reprint 2009, Vol 2, Chaukhambha Prakashana, Varanasi, PP 256 (Ma.Ni.1/56).

28. Vagabhata: Astanga Samgraha, Prof. K.R. Srikantamoorthy, $4^{\text {th }}$ Ed, Vol 3, Chaukhambha Orientalia, Varanasi, 2005. PP 215 (A.S. U 25/24)

29. Sushruta: Sushruta Samhita, Edited by P.V. Sharma, Ed 2005, Vol 2, Chaukhambha Visvabharati, Varanasi, PP 106 (Su.Ni 16/29)

30. Madhavakara: Madhava Nidana, Prof, K.R. Srikantmurthy $5^{\text {th }}$ Ed 2003, Vol 2, Chaukhambha Orientalia, Varanasi, PP 187 (Ma.Ni.56/23).

31. Bhavamishra: Bhavaprakasha, Prof, K.R. Srikantmurthy; Ed 2005, Vol 2, Chaukhambha Krishnadas Academy, Varanasi, PP 744 (Bha Ma Kn 66/66)

32. Vangasena: Commentary; Kaviraj Sri Shaligramji Vaisya, Ed 1996, Chaukhambha Sanskrita Bhavana, Varanasi. PP 706 (V S 65/46)

33. Hareet: Hareet Samhita; Pandit Hariprasad Tripati, $\mathrm{I}^{\text {st }}$ Ed, 2005, Chaukhambha Krishnadas Academy, Varanasi. PP 440 (Ha Sa 46/7-8)

34. Vagabhata: Ashtang Samgraha, Prof. K.R. Srikantamoorthy, $4^{\text {th }}$ Ed, Vol 3, Chaukhambha Orientalia, Varanasi, 2005.PP 215 (A.Sa. U 25/24) 
35. Stedman's Medical Dictionary, Lippincott Williams \& Wilkins Baltimore, Maryland, $28^{\text {th }}$ Ed, PP 315:2169

36. Sathe P. V., A textbook of community dentistry, $1^{\text {st }}$ ed, Hyderabad, Paras Medical Publisher; PP 84

\section{Source of Support: Nil \\ Conflict of Interest: None Declared}

How to cite this URL: Ankush Bhardwaj \& H S Bali: An Inside Review Of Danta Shareer W.S.R To Krimidanta (Dental Caries). International Ayurvedic Medical Journal \{online\} 2020 \{cited December, 2020\} Available from: http://www.iamj.in/posts/images/upload/5376 5381.pdf 